\title{
ENTRE A UTOPIA BARBOSIANA E A REALIDADE DE CARAVELAS: O PENSAMENTO POLÍTICO-CONSTITUCIONAL DA MONARQUIA DE 1824 E DA REPÚBLICA DE 1891
}

\author{
Alexandre Pedro Moura D'Almeida Guilherme ${ }^{159}$ \\ Guilherme Miraldi da Silva Santos ${ }^{160}$
}

Recebido em: 27/10/2017

Aprovado em: 14/11/2017

\begin{abstract}
RESUMO
O pensamento político-constitucional que envolve a formação da Monarquia brasileira de 1824 e da República de 1891 é fundamentalmente produto da recepção das teorias que circulam nos países cêntricos em seu tempo. A forma como essas ideias são recebidas e aplicadas diferem na proposição ideológica de cada um dos personagens históricos. Federalista, republicano, liberal radical e idealista, Rui Barbosa é o principal personagem na elaboração da Constituição de 1891. Monarquista, liberal oitocentista, ilustrado e realista, Marquês de Caravelas é o principal personagem na elaboração da Constituição de 1824. A Monarquia durou 65 anos e tinha como objetivo a formação do Estado brasileiro. A República de 1891 durou 39 anos e tinha como objetivo a democratização do país e a libertação do povo. A República foi um fracasso desde o início, já a Monarquia foi capaz de criar um Estado. A diferença de abordagem metodológica, a sujeição intelectual nacional e o pensamento desses personagens é o que se propõe a investigar, para tanto utilizasse uma revisão bibliográfica específica, assim como a revisão dos textos escritos pelos personagens escolhidos.
\end{abstract}

Palavras-chave: Pensamento político brasileiro; idealismo utópico; idealismo orgânico; constitucionalismo brasileiro.

\section{INTRODUÇÃO}

Com a independência e o fim do colonialismo, abriu-se espaço para a criação do estado brasileiro, já o tipo de estado que seria originado dependeria da recepção das ideias políticas em evidência nos países cêntricos. Esse evento histórico, marca no país o início do

\footnotetext{
${ }^{159}$ Mestrando em Direito pela Universidade Veiga de Almeida. Especialista em Direito e Processo Penal pela Universidade Cândido Mendes. Advogado.

${ }^{160}$ Mestrando em Direito pela Universidade Veiga de Almeida. Especialista em Direito Público pela Faculdade Damásio de Jesus. Advogado.
} 
constitucionalismo. Sinteticamente, poder-se-ia dizer que alguns pensamentos políticos específicos irão influenciar a constituinte: o pensamento liberal, o pensamento conservador, o pensamento monárquico, o pensamento federativo. O pensamento liberal era tido como de esquerda e o conservador como de direita. O partido conservador era monarquista, se dividindo entre a construção de um estado monárquico de direito e outros com a criação de um estado despótico ilustrado.

Em 1824 foi então proclamada a Constituição Monárquica do Império do Brasil, cujo projeto envolvia um estado forte com uma coroa forte, detentora do poder moderador e do poder executivo. O grande objetivo do constituinte era de se iniciar a criação de um estado, pois, o mesmo, alegadamente, não existia. $\mathrm{O}$ ordenamento jurídico elaborado na Constituição buscava estabelecer um misto de liberdade com ordem; introduz o poder moderador que tem no imperador o papel crucial da condução política do país. José Joaquim Carneiro de Campos, o Marquês de Caravelas, é o principal personagem na história do Direito brasileiro no que tange a criação da Constituição monárquica. O projeto de sua autoria visava à criação de um estado onde antes não existia e, hodiernamente, pode-se dizer que o Marquês foi bem sucedido na criação do estado brasileiro.

Avançando no tempo, com a ascensão do pensamento liberal de esquerda, o cenário político passa combater a Constituição de 1824, afirmando que a mesma está velha e que não representa os interesses nacionais de seu tempo, além de acusa-la de ser despótica. A exceção se faz ao pensamento de Joaquim Nabuco, personagem que acredita que não existem condições reais de se gestar uma república democrática, tendo em vista a inexistência de uma nação estabelecida. O pensamento liberal triunfa e por meio de golpe militar contra o império, outra constituinte é formada com o intuito de retirar o caráter monárquico do Estado dando origem à Constituição da República dos Estados Unidos do Brasil de 1891. Foi inaugurada no país uma república federativa com grande influência do liberalismo inglês e pensamento político federativo norte-americano. A Constituição republicana teve como um de seus principais autores Rui Barbosa, sendo também destacado personagem desse período histórico que marcou a república velha. No entanto, a inauguração da república foi um grande fracasso republicano e democrático.

A importação de ideias dos países cêntricos para a periferia demonstra a condição de sujeição ideológica em que se encontram os estados periféricos. Os discursos políticos giram entorno do atraso nacional em relação ao centro. Buscando suprir essa inferioridade e se aproximar do mundo civilizado, a técnica utilizada é a de introdução dos pensamentos evoluídos do centro do mundo. A forma como isso se daria é divergente, dando azo à 
formação de duas correntes de pensamento aclimatadas em solo nacional: a dos idealistas orgânicos e a dos idealistas utópicos.

Qual a diferença de abordagem política-constitucional entre o pensamento político do Marquês de Caravelas e de Rui Barbosa? Buscando responder essa pergunta, esse trabalho quer estudar o pensamento político de José Joaquim Carneiro de Campos e de Rui Barbosa. Para tanto, têm-se como objetivos específicos: (i) destacar a condição periférica do Brasil e as proposições de mudança da realidade local; (ii) analisar o pensamento político-constitucional de José Joaquim Carneiro de Campos, o Marquês de Caravelas; (iii) analisar o pensamento político-constitucional de Rui Barbosa; e por último tecer algumas considerações finais. O método empregado é o de revisão bibliográfica e de extração das ideias por meio da análise dos escritos dos autores investigados.

\section{PENSAMENTO POLÍTICO BRASILEIRO E O FORMALISMO}

No Brasil, produto de uma sensação secular das elites, assim como nos países ibéricos, há uma grande percepção de atraso em relação à evolução de suas instituições quando comparado aos países do atlântico norte, principalmente em relação à América do Norte e a Europa ocidental. Há também, uma grande sensação de deslocamento espacial, pelo fato de estar distante do lugar onde se encontra a dita civilização ocidental e por "[...] $]$ se acharem excluídas de um "centro" do mundo, mais importante e superior[...]”(LYNCH, 2013, p.734). Essa condição é recebida e internalizada pelas elites brasileiras, reconhecendo uma situação de inferioridade, motivo pelo qual não se fala em criação de teorias, fala-se na criação de pensamentos, dado a sua reflexão e caráter local. Estes pensamentos são influenciados pelas teorias dos países cêntricos por serem mais evoluídos e preparados para criar uma teoria. Esse reconhecimento faz com que, no comportamento das elites, se vislumbre uma busca incessante em se aproximar do centro e superar essa condição de atraso.

Essa sujeição era confirmada pela divisão internacional do trabalho e também pela divisão internacional da produção intelectual. Por estarem distantes da realidade do centro, esses países periféricos se viam numa subordinação intelectual, no sentido de que tudo produzido no cenário local jamais superaria ao dos países centrais. O povo da periferia deveria ser instruído e educado pelos mais civilizados e instruídos, razão que leva a elite a buscar uma educação de ' 1 mundo', superando uma educação atrasada da periferia. A elite 
brasileira então, se vê na posição de condução do país para próximo dos países cêntricos, adotando as ideias e filosofias do estrangeiro como estratégia de desenvolvimento local.

O posicionamento dos países cêntricos era também de desprezo pelos menos desenvolvidos, colocavam-se numa posição de superioridade, ditando à periferia aquilo que deveriam adotar se quisessem superar sua condição de atraso. Não admitiam a possibilidade de surgimento de uma teoria por parte desses países isolados; a eles cabiam somente o aparecimento de um pensamento local, resultado de uma interpretação deturpada de alguma filosofia cêntrica. Essa postura cêntrica reforçava e influenciava o reconhecimento de inferioridade das elites periféricas, vendo-se forçadas a superar essa condição.

\footnotetext{
"Entre nós, foi Joaquim Nabuco quem, em 1900, fez a clássica descrição do dilema do mazombo, fraturado entre uma jovem pátria "geográfica", periférica, lugar do sentimento e da natureza (o Brasil), e uma antiga pátria "espiritual", cêntrica, lugar da inteligência e da civilização (a Europa). [...] Em1932, em Brasil errado, Martins de Almeida diria: "O brasileiro é um exilado dentro da própria terra" (Almeida, 1932:53).Quatro anos depois, Sérgio Buarque de Holanda se limitaria a repetir a fórmula de Almeida, em Raízes do Brasil: "Somos ainda uns desterrados em nossa terra” (Holanda, 1936:3).” (LYNCH, 2013, p. 738-739)
}

Essa percepção de não condução da própria historicidade começa a mudar entre nós com a introdução de um pensamento nacionalista a partir de 1922 com Oliveira Viana e tantos outros trabalhos que depois se seguem. Aqui, não nos interessa explorar essas ideias, haja vista o objetivo de analisar o pensamento político-constitucional do Marques de Caravelas e de Rui Barbosa, portanto, anteriores.

Explicada a condição de sujeição percebida pela elite local, surgem basicamente duas formas de se lidar com as ideias importadas para solo nacional: os idealistas orgânicos e os idealistas utópicos. Isto é percebido no constitucionalismo brasileiro e na forma com que as ideias foram adaptadas na história do pensamento constitucional. Ambas as proposições são idealistas, porque se trata da implementação de ideias externas, tipos ideais, no entanto, o idealismo utópico se orienta para a aplicação integral das teorias estrangeiras, sem se preocupar com a realidade local, no sentido de que a sua implementação irá forçar a realidade local a se adaptar; já o idealismo orgânico quer promover um filtro nessa recepção, analisando a realidade local e conduzindo as teorias importadas a uma adaptação, uma aclimatação, que permitisse resolver os reais problemas dessa diferente sociedade.

A diferença entre a realidade fática e a realidade jurídica dos modelos políticos trazidos é denunciada por Guerreiros Ramos (1966, p. ) e chamada, por ele, de formalismo. O formalismo se caracteriza com o afastamento da norma jurídica da realidade fenomênica. Nessa lacuna, defende o autor que se abre espaço para o que ele chama de jeitinho brasileiro, 
explicado como incapacidade de compreender e se ajustar, a sua maneira, ao sistema normativo, resultando numa adaptação fática que resolvesse o problema no mundo real. Interessante perceber que Guerreiro Ramos, em sua obra "Administração e contexto brasileiro", critica essa lacuna deixada pelo formalismo, comum nos países de condição periférica, indicando uma falta de percepção social e material da sociedade que se observa, porém, advoga a necessidade de se usar o formalismo como estratégia de desenvolvimento nacional, forçando determinada sociedade a se adaptar a uma realidade jurídica avançada; defendendo ainda, a necessidade de adaptar a utilização dos modelos cêntricos à realidade local, buscando resolver a problemática nacional.

\section{A MONARQUIA DO MARQUÊS DE CARAVELAS}

3.1 Brevíssimo resumo histórico de sua trajetória política

José Joaquim Carneiro de Campos nasceu em Salvador no dia 4 de março de 1768. Estudou em Coimbra, onde se formou em Direito e Teologia. Foi oficial de Secretaria de Estado da Fazenda em Lisboa durante o império luso-brasileiro. Sua principal influência intelectual foi Aristóteles e Monstesquieu, caracterizando um pensamento convergente para a prudência, moderação e conciliação. Foi também influenciado por Locke e Sieyes.

Com a independência, Carneiro de Campos foi deputado constituinte pela Bahia, sendo posteriormente escolhido como primeiro ministro por D.Pedro I. A assembleia constituinte inicialmente fracassou em lidar com as divergências políticas, tendo Caravelas dissolvido a assembleia por decisão do imperador. Posteriormente foi nomeado para o Conselho de Estado e encarregado pelo imperador de elaborar um novo anteprojeto que desse conta das divergências políticas e que fosse bem sucedido em assegurar o poder do imperador, afastando a esquerda mais liberal, federativa, e equilibrando os desejos da direita conservadora. O prazo dado a Carneiro foi de 8 dias, possuindo como base o projeto da família Andrada.

Duas importantes introduções de Carneiro marcaram o anteprojeto: a introdução do Poder Moderador e certa descentralização politica com a criação dos Conselhos Gerais de Província. O projeto foi aprovado e tendo sido outorgado pelo imperador em 24 de março de 1824 como a nova Constituição Política do Império do Brasil. No ano seguinte foi condecorado com o título de Visconde de Caravelas pelos serviços prestados. Em 1826, 
concorreu ao senado pelo estado da Bahia, tendo sido escolhido pelo imperador e elevado de Visconde para Marquês, passando a chefiar o senado nesse mesmo ano. Quando da abdicação de Pedro I, fora indicado como membro da Regência Trina Provisória. Era oposto as tentativas de reformar a constituição, seja para retirar o poder do imperador ou para introduzir uma federação, indicando que a Constituição 1824 era extraordinária em equilibrar um poder forte de estado na monarquia sem que fosse despótica e garantir uma margem liberal sem que gerasse anarquia, ou "monarquia sem despotismos e liberdade sem anarquia" (CARAVELAS apud LYNCH, 2014, pg. 53). O Marquês veio a falecer em 8 de setembro de 1836.

\subsection{Pensamento político-constitucional}

O Marques de Caravelas defende a união entre Estado e Igreja, no sentido de que a religião seria capaz de manter a ordem no tecido social. Os dogmas religiosos conteriam o ímpeto da população, o que promoveria auxílio na manutenção da ordem, um posicionamento estratégico no seu pensamento político. No entanto, Caravelas adota um posicionamento liberal, a época, quanto à posição da Igreja no Estado, consagra o catolicismo como religião oficial, mas, garante a liberdade de culto e a liberdade de consciência (Art. $5^{\circ}$ da Constituição de 1824).

\footnotetext{
Ora, a minha consciência, a minha crença e as minhas opiniões são de tal sorte minhas, que ninguém mais podem pertencer; elas residem bem recatadas no santuário mais impenetrável da minha alma, onde nem as leis, nem o governo nem os homens podem ter ingerência alguma. Só Deus ali entra, e só a ele devo dar estreitas contas dos meus pensamentos. [...] Jesus Cristo, o nosso divino mestre, expressamente o disse - Regnum meum non est de hoc mundo - e nós, que estamos aqui reunidos para darmos instituições que formem a felicidade temporal dos nossos concidadãos, devemos também professar que nada temos com a religião de cada um. Os nossos poderes podem somente porvir do pacto social.(CARAVELAS apud LYNCH, 2014, p. 122-123)
}

Quanto à forma de governo, advogava a necessidade de se criar um estado equilibrado e misto. Para ele, só existiam quatro formas de governo: “a república pura ou democrática, a república representativa ou aristocrática, a monarquia pura ou absoluta e a monarquia constitucional, representativa, temperada ou limitada" (LYNCH, 2014). Numa democracia, a vontade do povo é soberana e se manifesta por meio da irrestrita manifestação dessa vontade, o que significa que ninguém pode limitá-la. Na aristocracia, o governo é dirigido por um pequeno grupo de pessoas com interesses específicos. A monarquia absoluta é aquela em que os poderes são concentrados na mão do soberano, fazendo com que as casas legislativas sejam apenas figurativas. Carneiro sustenta que essas três formas de governo são cíclicas, no sentido 
de que uma democracia tem a capacidade de se transformar numa aristocracia quando alguns grupos obtém o poder e que esse último pode se transformar numa monarquia, caso haja concentração de poder. O caráter cíclico se explicaria com a vontade posterior de se restaurar o governo do povo e assim entrando num vício irremediável. Caravelas afirma que o único governo capaz de afastar esse caráter cíclico é a monarquia representativa.

Tem-se procurado conferir uma grande força ao elemento democrático e, com esta
força, sustentar a proposição da não-vitaliciedade do Senado. Já serviram os mesmo
princípios para se querer abolir o Poder Moderador ou amalgamá-lo com o Poder
Executivo, o que reduzia o Moderador ao mesmo que era o Chanceler do Reino, que
glosava as leis. Ora, Senhores, se tais princípios passarem, quem governa o Brasil?
A Câmara dos Deputados? Que elemento é este? O democrático. Que governo nós
teremos? O oligárquico. O que se segue dele? A anarquia; e atrás da anarquia, o que
vem? O despotismo, porque, depois que veem correr rios de sangue, os povos
procuram um homem que os livre do estado de desgraça a que têm chegado e que os
dirija; e este, aproveitando-se da ocasião, os governa despoticamente, como fez
Napoleão. (CARAVELAS apud LYNCH, 2014, p. 133)

A monarquia representativa de Caravelas é baseada num governo constitucional que garante ao monarca o poder executivo e o poder moderador. A administração do estado permanece nas mãos do imperador, que a exerce por meio de seus Ministros de Estado (art. 102 da Constituição de 1824). O poder moderador é o poder que equilibra as forças do estado, seu objetivo é zelar pela independência e harmonia entre os poderes, sendo a chave da organização política do estado. O senado é responsável pelo equilíbrio do sistema político, sendo casa de assento vitalício (art. 40 da Constituição de 1824), é o local destinado aos aristocratas do país. A câmara dos deputados é casa de assento temporário destinado ao povo, que juntamente com o senado formam a Assembleia Geral (poder legislativo) responsável pela edição das leis, com a sanção final do Imperador. A câmara podia ser destituída caso o Imperador entendesse imperioso para a salvação do Estado.

O objetivo do Marquês de Caravelas era a de criar um Estado que equilibrasse as forças políticas, monarquia, aristocracia e povo, mas que garantisse ao imperador a sua governabilidade, com instrumentos de intervenção e poderes de efetivos. O que não significa dizer que havia despotismo, pois, trata-se de um sistema constitucional, cuja carta maior encontrasse num patamar de superioridade a todos os agentes políticos. O poder legislativo possuía papel político destacado, tendo as leis força para obrigar inclusive o imperador. Para evitar um governo do legislativo, Caravelas cria um sistema no qual a publicação das leis dependa da sanção do imperador, equilibrando o sistema político. O poder moderador é a chave do sucesso do Estado de Caravelas, deposita nele a governabilidade e equilíbrio na condução do país. Nesse sentido, o esforço intelectual do Marquês na criação de uma 
verdadeira teoria política-constitucional é recompensado com exportação de seu projeto, tendo influenciando muito a Constituição Portuguesa de 1826.

Temos visto que a qualidade distintiva das repúblicas representativas á a preponderância do Poder Legislativo; se perde a preponderância, já não é república, passa a ser monarquia; e que, para que seja moderada ou representativa, é indispensável que o Poder Legislativo e o chefe da nação tenham, cada um, uma influência igual na organização das leis. Porque, se esta influência não for igual, e for maior a do monarca, já então a monarquia passará a ser uma monarquia absoluta: o corpo legislativo perderá o voto deliberativo e os seus membros não serão mais do que simples conselheiros do monarca. Se for maior a influência do Poder Legislativo, então este será preponderante e teremos por consequência uma república, em que o chefe da nação, posto que denominado Rei ou Imperador, não será mais do que um arconte, cônsul ou doge; um mero executor das leis. Pelo que duas condições são especialmente precisas para que se verifique a monarquia representativa ou temperada. Primeiro: que, na formação das leis, o monarca tenha tal influência, que possa contrabalançar as resoluções do Poder Legislativo, e que a sua autoridade seja capaz de forçá-lo a não sair dos limites dos seus poderes, e a encerrar-se no texto da Constituição; segundo: que, da outra parte, os representantes da nação, em quem muito principalmente reside o Poder Legislativo, concorram com o monarca na criação da lei e modifiquem ou temperem a autonomia do monarca. (CARAVELAS apud LYNCH, 2014, p. 127)

O Marquês de Caravelas era consciente de que a população brasileira era composta na sua maioria por ignorantes, pessoas que não haviam estudado e, portanto, não haviam sido iluminadas. Dessa forma, defendia que a governabilidade deve ser direcionada ao povo brasileiro por aqueles que ocupam os postos de grande relevância política, estes o fazem pelo mérito intelectual e moral. Caravelas acreditava que somente o conhecimento, produto da filosofia das luzes, é capaz de transformar o homem; esse homem educado seria o único com capacidade intelectual de alterar a realidade. Justifica, assim, os cargos de alto prestígio político dados a esses ilustrados. Defende que a aristocracia brasileira não é feudal e sim meritocrática, sendo está indispensável na condução do Estado, momento em que sem a sua condição intelectual, bom senso, boa moral e maturidade, o país sucumbe.

Acreditando nessa necessidade, o Marquês de Caravelas credita ao Estado a função de iluminar os povos ignorantes, educando-os para um futuro em que possam ter participação política. Ele sabia da real condição do país, e pautava toda a sua estratégia de desenvolvimento nacional com relação a essa realidade, indicando a necessidade de criar leis e de se fazer planejamentos que fossem capazes de fazer o país avançar. Rechaçava a possibilidade de se implementar um sistema político, como o federativo, ou de se importar uma legislação, sem que se considerasse a real situação do país. Caravelas não era um idealista, pautava seus posicionamentos políticos como fruto de uma observação cautelosa da realidade nacional, pensando nos efeitos negativos que os tipos ideais poderiam causar numa realidade completamente distinta e peculiar quando em comparação com os países cêntricos. 
As leis de um país devem ser acomodadas às circunstâncias em que ele se acha, devem ter estreita relação com o seu tempo e os costumes dos seus habitantes. [...] Temos o exemplo de Sólon. Quando foi questionado sobre a bondade das leis que havia dado aos atenienses, respondeu: "Dei-lhes as que mais lhe podiam convir." É necessário legislar segundo as circunstâncias. Esta é a grande regra que todo legislador deve ter diante dos olhos. O contrário é - como costumam dizer escrever na areia. (CARAVELAS apud LYNCH, 2014, p. 137)

Caravelas defendia a necessidade de se criar um Estado que desse conta da realidade e, fundamentalmente por isso, afastava o discurso latente de se criar um Estado federativo que tivesse como eixo principal a liberdade quase que absoluta. Além de considerar que a possibilidade de anarquia fosse possível, levava em conta a real condição do povo brasileiro, ainda deseducado e não conhecedor do que liberdade significaria. Por isso, quando desenhou as instituições na Constituição de 1824, tentou criar um estado moderado, entre ondem e liberdade. A ordem seria o eixo que mantém o estado vivo e a liberdade seria o eixo propulsor existente, não ilimitado, onde o povo poderia o seu significado com o tempo. A criação de um estado completamente liberal, para o Marquês de Caravelas, levaria a gestação de um estado comandado por interesses privados, interesses oriundos dos partidos de cada província. Com um povo não iluminado, isso se daria com maior facilidade, pelo fato da facilidade de acreditar em qualquer discurso político convincente, assim, receberiam acriticamente esses discursos, desarmados de juízo diverso.

Com isso, o papel dos políticos seria também o de criar novos costumes dentro do sistema político vigente, educando o povo às novas instituições, para que, no futuro e depois de iluminados, pudessem decidir os rumos das instituições. A religião tinha papel fundamental na manutenção dessa dinâmica política e social, pois, acreditava Carneiro de Campos que ela é fundamental na manutenção da ordem moral e social, mantendo o tecido social apaziguado. Não acreditava que a pena criminal por si só seria capaz de afastar a incidência dos crimes, defendia que a religião ajudaria na criação da ordem.

Senhores: se queremos ser livres e felizes, não desprezemos, portanto, os meios
indispensáveis, porque são essenciais para firmarmos a nossa felicidade e liberdade.
Tenhamos sempre presente estes princípios, que são axiomas de Direito Público:
não há liberdade sem um poder que a sustente, não há poder sem respeito.
Enganamo-nos, se nos persuadimos que a obediência de um grande povo não se
conduz por ideias abstratas. Os trabalhos a que a maior parte se dedica e a falta de
tempo e meios para se entregar a meditações mais profundas a põe na estrita
necessidade de se guiar quase sempre por sensações somente; seu grande mestre é o
exemplo. (CARAVELAS apud LYNCH, 2014, p. 145)

Não concebia os EUA como modelo de referência para o Brasil, advogava no sentido de que a Inglaterra possuía melhores referências, no entanto, não recebia de forma acrítica 
nenhuma influência política externa, seja ela inglesa, francesa ou qualquer outra. Não negava a importância dos EUA, indicando que se houvesse algo que servisse ao país não se furtaria de considerar, mas não acreditava na importação de tipos ideais sem a sua efetiva confrontação com a realidade nacional. Da Inglaterra, assim como da França, retira os exemplos de monarquia consolidada, da criação de uma ordem. Reconhecia a diferente gestação dos EUA, assim como das diferenças históricas e culturais, por isso sua temerosidade com qualquer prática importada sem o devido abrasileiramento.

Caravelas adotava um discurso de defesa do liberalismo econômico, fruto de seu pensamento liberal típico do sec. XVIII. Acreditava na liberdade individual como força motriz da economia; como condutora da produtividade e da empregabilidade. Indica, contudo, que o país é ainda muito atrasado economicamente, principalmente no que tange a tecnologia empregada na agricultura (atividade econômica da época). Esse discurso de atraso do país se repete quando se trata das instituições políticas, educação e cultura do povo, demonstrando, portanto, a necessidade de se trabalhar o país de forma resolver os problemas da realidade local para superar o atraso, sem devaneios ao importar ideias e sem a sua efetiva adaptação e utilidade ao país.

Quanto ao Poder Judiciário, Carneiro Campos defendia a sua independência e o seu restrito papel de aplicador das leis. Não outorgava ao Judiciário a capacidade de interpretar as leis além daquilo que estava escrito, para isso, defendia que o legislador deveria ser capaz de fazer leis claras e sem obscuridades, pois, a possibilidade dos juízes interpretarem as leis era visto como a porta para a arbitrariedade. Não seria permitido ao Judiciário da época aplicar aquilo que hoje se chama de ponderação, ficando tal sistema na mão do Imperador, por meio do Poder Moderador, no qual decidiria sobre a necessidade da pena de acordo com os interesses da nação. O Judiciário possuía um papel secundário de aplicador da lei. A interpretação das leis e da Constituição ficava a cargo do Poder Legislativo. Caravelas entendia que quanto à Constituição "pode a Câmara interpretá-la, isto é, declarar o seu sentido, sem, contudo, ampliar nem restringir a sua disposição. Chama-se essa declaração autêntica, porque obriga como lei. As outras declarações e interpretações são doutrinárias; cada um pode seguir esta ou aquela."(CARAVELAS apud LYNCH, 2014, p.190)

\section{A REPÚBLICA FEDERATIVA DE RUI BARBOSA}

4.1 Brevíssimo resumo histórico de sua trajetória política 
Rui Barbosa nasceu em Salvador, na província da Bahia em 1849. Desde os cinco anos era considerado brilhante, tendo se graduado Bacharel em Direto na Faculdade de Direito do Largo São Francisco em São Paulo no ano de 1870. No ano seguinte retornou a Bahia para iniciar sua carreira de advogado. Em 1872 iniciou na carreira de jornalista no Diário da Bahia. Em 1877 foi eleito deputado na província da Bahia e no ano seguinte foi eleito deputado da Câmara dos Deputados. Promoveu a reforma do ensino no ano de 1881, tendo se destacado também nesse período como um abolicionista de forte atuação política naquela campanha. Morou durante grande parte da sua carreira na cidade do Rio de Janeiro.

Rui tinha como forte referência intelectual o pensamento político norte-americano e o pensamento liberal inglês. Republicano e federalista acreditava no fim do regime monárquico, marcando início para uma reforma institucional que originaria a federação e a república nacional. Rui Barbosa elabora o projeto de constituição que iria entrar em vigor em 1891, marcando o início da República democrática e liberal. Quanto aos ideais liberais e federalistas de Rui, a República se demonstrou um fracasso do início ao fim, marcando o período de sua intensa participação e insatisfação no cenário político, caracterizado principalmente por seu discurso da necessidade de protagonismo do Judiciário para o cumprimento da Constituição e da efetivação da República. Suas desilusões com a realidade oligárquica dominadora também marcou a República velha. Rui Barbosa, tendo em mente o novo papel que destinava o judiciário, introduz no constitucionalismo nacional dois instrumentos de controle judicial, oriundos da cultura jurídica norte-americana: o controle de constitucionalidade e o habeas corpus.

Fugiu do Brasil entre os anos de 1893 e 1895, tendo passado por Buenos Aires, Portugal e Inglaterra. Seu exílio ocorreu por conta de suas posições críticas e contrárias ao governo militar do início da República, motivo que levou a sua perseguição. Foi senador por quatro vezes, além de ministro da fazenda no início da República e membro fundador da Academia Brasileira de Letras em 1897; presidente da mesma entre 1908 e 1919. Era considerado um grande orador e intelectual brilhante. Foi candidato à presidência da República em 1904, 1910, 1914 e em 1919, nunca tendo ganhado. Veio a falecer em 1923, em Petrópolis no Rio de Janeiro.

\subsection{Pensamento político-constitucional}


Rui Barbosa não reconhece o poder pertencente à coroa, alegando que o poder da monarquia é produto de uma "ficção imponente" (BARBOSA, 1999, p.11); pacto de um grupo de ministros que, ao criarem a monarquia constitucional, outorgam todo o seu poder e autoridade ao monarca. Acreditava que esse tipo de Estado era eivado de arbitrariedade e despotismo. Rui acreditava no fim da monarquia constitucional, com a libertação do homem das amarras autoritárias, o que daria azo a uma reforma estrutural do Estado, de cima para baixo, criando uma superestrutura essencialmente republicana, democrática e presidencialista; ao estilo americano. Apesar de apaixonado pelo parlamentarismo (LYNCH, 2014, p. 222), vê no presidencialismo a significância máxima da representatividade da vontade popular, sendo, portanto, o que melhor se alinhava com seus ideais doutrinários de República. Rui, por tal motivo, passou a afastar a ideia de parlamentarismo. O desacordo entre os poderes públicos e a opinião geral é o maior atentado que o parlamentarismo poderia cometer (BARBOSA, 1999, p.12-15). Idealizava que um sistema realmente democrático seria aquele representado pela vontade da maioria, do consenso nacional por meio do voto.

O voto é a primeira arma do cidadão. Com ele vencereis. Agora, se vo-lo roubarem, é outra coisa. Com ladrões, como ladrões. Quando a ofensiva nos arrebata um direito, até onde o exigir a recuperação deste, até aí deve ir a defensiva. Comem-vos os parasitas, comendo-vos o imposto? Pois é cortardes os mantimentos aos parasitas. Já vo-lo disse. Como? Recusando-vos a pagar os tributos legais? Não: apoderandovos, pelas urnas, da função legislativa, que é a função do imposto. Quem o não vota, não pode ser obrigado a pagá-lo. Agora, se vos enxotarem das urnas, se vos tangerem do Parlamento, e, salteando a soberania nacional, vos exigirem impostos, que não votastes, porque não elegestes a quem os votou, isso é outro caso. Com salteadores, como com salteadores. Na guerra, como na guerra. O povo não é obrigado a pagar senão o imposto que votou. (BARBOSA, 1960, p. 464-465)

O eixo central da argumentação de Rui Barbosa pode ser dividido em duas partes, primeiro: na autodeterminação da sociedade civil e descentralização política, possuindo como dogma a liberdade individual e capacidade de cada ente federado se autodeterminar; segundo: pela colocação do judiciário como poder destacado e controlador dos outros poderes. Rui Barbosa advogava a necessidade de ter um Poder Judiciário forte, independente e mais ativista. Com a ausência do poder moderador, seria papel do judiciário equilibrar o sistema político, controlando os atos dos outros poderes por meio do controle de constitucionalidade introduzido na Constituição de 1891. Defendia também a temporalidade do mandato do senado, vitalício no império. Argumentos liberais e com base num pensamento radical de consciência pública democrática, defendia além dessas medidas, a extinção da justiça administrativa, eleição direta, descentralização política. Rui queria um Estado de Direito idêntico ao que via nos Estados Unidos. 
Sob o sistema federal, escreve o grande expositor da soberania parlamentar na Inglaterra, confrontando-a com o regimen que acabamos de adoptar, "não succede a assim. A supremacia legal da Constituição é imprescindivel á existência do Estado. A gloria dos fundadores dos Estado Unidos consiste em haverem descoberto, ou implantado combinações, sob as quaes a Constituição se tornou tão real quão nominalmente o direito supremo do paiz; resultado a que chegaram, aderindo a um principio muito simples, e engenhando um mecanismo adequado para o pôr em acção". Esse principio (falla o chanceller Kent) é o de que "todo acto do Congress, ou das legi legislaturas de Estados, que de qualquer modo contravierem a Constituição dos Estados Unidos, é necessariamente nullo". E o orgão activo dessa supremacia é o Supremo Tribunal Federal. (BARBOSA, 1892, p. 18)

Sua principal influencia intelectual foi John Stuart Mill, a partir dele que Rui cria o seu ideário de democracia liberal, fundada num moralismo político e pelo culto as leis. Rui acreditava que a liberdade política do povo seria capaz de trazer mudanças no cenário nacional e, para tanto, se fazia necessário importar um modelo político constitucional que reunisse essas características. Entendia que a educação possuía um papel fundamental para o sucesso da República. Nesse sentido, somente o sistema político constitucional norteamericano, consistindo de uma república virtuosa, democrática, federativa e presidencialista, seria capaz de alterar a realidade local. Rui acreditava que o país estava muito atrasado frente às grandes nações e, para que tentasse alcança-las, seria fundamental copiá-las naquilo que havia de melhor e mais avançado, aproximando a nossa realidade à deles; para ele, os EUA representava isso.

Completamente avesso na junção do Estado com a Igreja, Rui pugna pela sua separação, dado a sua influência norte-americana. Defensor assíduo do liberalismo, pautava todo o seu posicionamento político na defesa das liberdades. Isso significava a defesa da liberdade de crença e de culto religioso, indicando que não se tratava de papel do estado adotar religião nem se meter nesse assunto, pois, o objetivo do estado era diverso ao da igreja.

Suas contribuições para a Constituição de1891 foram: (i) a criação de um sistema político de eleições diretas, com um aumento significativo do eleitorado, impedindo, no entanto, a participação de mulheres, militares e analfabetos, pois, acreditava que esses últimos, devido a sua condição intelectual, poderiam não compreender e comprometer os rumos do país; (ii) um sistema político descentralizado, com estados federados e independentes. As antigas províncias, agora Estados indissolúveis da República, não sofreriam ingerência da União Federal a não ser nos casos de exceção permitidos pela Constituição; (iii) a criação da Justiça Federal em todo o país, assim como da Suprema Corte; (iv) para equilibrar os poderes políticos, coloca o Poder Judiciário como o guardião da constituição, ao melhor estilo norte-americano, lhes destinando um papel de equilíbrio entre 
os poderes executivo e legislativo da República; (v) introduz o controle de constitucionalidade difuso no cenário nacional, sendo papel daquela recém-formada Corte Suprema o de julgar as legislações e atos emanados de outros poderes, atestando a sua (in)constitucionalidade; (vi) o impeachment do presidente da República é introduzido nos art. 53 e 54 daquela Carta constitucional; (vii) a introdução do habeas corpus como instrumento de garantia do direito de liberdade, art.72, §22 da Constituição de 1891; (viii) a manutenção do instituto do júri (art. 72, §31 da Constituição de 1891). Rui Barbosa era um americanófilo; precisamente, dedicavase aos estudos dos pensamentos emanados pela cultura anglo-saxônica de língua inglesa, no entanto, curioso é o fato de que nunca esteve nos EUA.

\footnotetext{
No seio das nações que individualizam, para a civilização contemporanea, o typo da liberdade, politica ou civil- a Inglaterra e os Estados Unido - a palavra forense foi sempre um dos orgãos mais eminentes do desenvolvimento da consciência popular. Nenhum povo carece mais profundamente que este de senso jurídico, essa qualidade suprema das raças livres, cuja expansão constitue o segredo das maravilhas da democracia americana, cuja fraqueza, explica a ruina das instituições da monarchia representativa, e cuja decadencia crescente nos vae fazendo voltar, sob uma admiraravel constituição republicana, aos horrores, que preciptaram o primeiro reinado para o seu occaso tenebroso.(BARBOSA, 1892, p. 6)
}

Com o decorrer da sua carreira jurídica e política, Rui Barbosa observa todo o seu esforço intelectual, na construção de um cenário politico favorável à liberdade e ao desenvolvimento sistêmico das instituições, da boa moral e da honra, falhar miseravelmente. A nascitura República, com a lacuna no poder deixada pelo Poder Moderador se torna alvo de disputa para o preenchimento desse espaço, eis que os militares oportunamente aparecem num primeiro momento e acabam por metamorfosear a República em algo pior que o antigo regime. Rui Barbosa irá se insurgir contra tais abusos e passa a testar os instrumentos que introduziu na nova ordem constitucional, impetra uma ordem de habeas corpus contra a ordem de prisão de inúmeras pessoas do Marechal Floriano Peixoto. Sua alegação principal era de que o estado de sítio declarado pelo Poder Executivo era inconstitucional e, portanto, todas as prisões eram ilegais. O que Rui não percebia era que o judiciário ainda não possuía prestígio ou poder político, além de não conhecer os recém-introduzidos institutos, para agir de acordo com a exegese criada por ele, tendo, nesse episódio, sido negada a ordem de soltura dos presos, até porque ameaçados pelo Marechal foram os ministros do Supremo Tribunal. Diversos estados de sítios foram declarados no início da República. Posteriormente, uma grande disputa oligárquica se apropria do poder.

Outra característica do pensamento político de Rui era a constante insatisfação com os rumos da situação política e econômica do país. A boa moral defendida por ele foi suplantada 
pela política oligárquica voltada para a manutenção do poder político e econômico, o que transformaria a sua idealizada democracia numa verdadeira oligarquia. Inúmeros discursos inflamados contra essa situação foram proferidos por Rui, todos sem os efeitos desejados no cenário político. Rui era um idealista, acreditava que as ideias, a educação e a boa moral, traduzidas num compromisso liberal individual, mas coletivo no plano político, seriam suficientes para a condução de um futuro próspero. A realidade foi implacável, derrubando os ideais de Rui Barbosa.

Uma espécie de maldição acompanha, ultimamente, o trabalho ingrato dos que se votaram à lida insana de sujeitar à legalidade os governos, implantar a responsabilidade no serviço da nação, e interessar o povo nos negócios do país. A opinião pública, mergulhada numa indiferença crescente, entregou-se de todo ao mais muçulmano dos fatalismos. Com o reinado sistemático e ostentoso da incompetência

cessaram todos os estímulos ao trabalho, ao mérito e à honra. A política invadiu as regiões divinas da justiça, para a submeter aos ditames das facções. Rota a cadeia da sujeição à lei, campeia dissoluta a irresponsabilidade. Firmada a impunidade universal dos prepotentes,

corrompeu-se a fidelidade na administração do erário. Abertas as portas do erário à invasão de todas as cobiças, baixamos da malversação à penúria, da penúria ao descrédito, do descrédito à bancarrota. Inaugurada a bancarrota, com o seu cortejo de humilhações, agonias e fatalidades, vê a nação falidas até as garantias da sua existência, não enxergando com que recursos iria lutar amanhã, ao menos pela sua integridade territorial, contra o desmembramento, o

protetorado, a conquista estrangeira. E, enquanto êste inevitável sorites enlaça nas suas tremendas espirais a nossa pátria, todos os sinais da sua vitalidade se reduzem ao continuo crescer dos seus males

e sofrimentos, sob a constante ação dos cancros políticos que a devoram, das parcialidades facciosas que a corroem, dos abusos, por

elas entretidos, que a lazaram de uma gafeira ignóbil.(BARBOSA, 1960, p. 563)

Uma situação interessante do pensamento de Rui é uma mudança de paradigma liberal vista no ano de 1919, no famoso discurso proferido no teatro lírico do Rio de Janeiro, conhecido como "A questão social e política no Brasil". Nesse discurso ele novamente afirma o seu posicionamento contrário as camarillas que haviam tomado conta do Brasil, afirmando que somente a grandeza do povo brasileiro, este sim dotado de realeza, por meio do voto inteligente, seria capaz de alterar essa realidade. Aqui, reconhece que o liberalismo exacerbado havia criado uma situação de desigualdade para com a classe trabalhadora, portanto, acreditava numa mudança legislativa, com o objetivo de proteger e melhorar a vida dessas pessoas. Acreditava ser fundamental essa para o Estado, além de ser o correto e virtuoso se fazer. Demonstra sua preocupação com as grandes diferenças na distribuição de riqueza, indicando a imperiosa necessidade de se criar um plano para retirar da pobreza extrema a população que se amontoava em lugares insalubres e inóspitos. 


\section{CONSIDERAÇÕES FINAIS}

Rui Barbosa, um homem virtuoso, de moral elevada e de proposição idealista, acreditava que a mudança de pensamento seria suficiente para provocar uma mudança na realidade nacional. Fiel as suas concepções ideológicas, não foi capaz de perceber o interesse oligárquico que se formava por detrás do seu discurso liberal Republicano e Federalista anterior a Constituição de 1891. Após 1891, percebe que aquilo que idealizara não se cumpre na realidade e passa, portanto, o resto de sua vida combatendo a ideologia oligárquica que se apropriou do poder. $\mathrm{O}$ fracasso da $1^{\circ}$ República se deu justamente por não perceber a realidade da sociedade nacional que possuía altos índices de analfabetismo e uma grande população de ex-escravos. O discurso liberal serviu aos interesses dos grandes latifundiários que só possuíam o interesse de ocupar o poder, além de se libertarem do controle da Monarquia; esses sim adquiriram liberdade para fazer o que quisessem.

O Marquês de Caravelas, com suas proposições ideológicas, fez aquilo que entendeu melhor de acordo com a análise da realidade que promoveu. Era um liberal clássico, mas adotara posições jurídicas que permitissem a criação de um Estado forte. Acreditava na possibilidade de que um sistema diferente do seu seria capaz de superá-lo, mas, tal somente ocorreria quando o estado estivesse formado, a nação estabelecida e o povo educado. A Monarquia por ele idealizada também não correu completamente como gostaria, tal aconteceu pelo fato de o poder moderador se ausentar em determinados momentos [não estava mais vivo quando isso ocorreu], além de que a ascensão do pensamento liberal, republicano e federalista americano, fez com que o plano monárquico se apresentasse como velho e atrasado no plano internacional. As monarquias naquele formato já não existiam no mundo civilizado, portanto, a mudança deveria ser imediata, sob pena de agravar a condição de atraso do país.

Embora Caravelas e Rui sejam personagens bastantes diferentes, partilham de um mesmo ideal: a necessidade de educação como forma de libertação do homem. As abordagens liberais, políticas e constitucionais eram distintas, uma marcada por uma análise sociológica realista, pela prudência e pela ordem com liberdade; o outro é marcado pela aplicação de uma teoria política importada integralmente, pelo motivo de ser tida como produto de países evoluídos e que o Brasil deveria se modernizar nesse sentido; a veneração da liberdade individual e pela descentralização do poder. Rui Barbosa era um idealista utópico, já Caravelas um idealista orgânico. A condição periférica do Brasil e a realidade política e social explicam a frustação de Rui Barbosa com o insucesso da tão sonhada República. A história do 
Marquês de Caravelas é muito pouco explorada na literatura, no entanto, devido importância estratégica que teve na formação do Estado Brasileiro, deveria se reconsiderar a necessidade de compreender melhor a história do Direito brasileiro e das ideias, com o intuito de compreender o arcabouço no qual a sociedade moderna se sustenta.

\section{REFERÊNCIAS}

BARBOSA, Rui. Escritos e discursos seletos. Rio de Janeiro: Editora José de Aguilar LTDA, 1960.

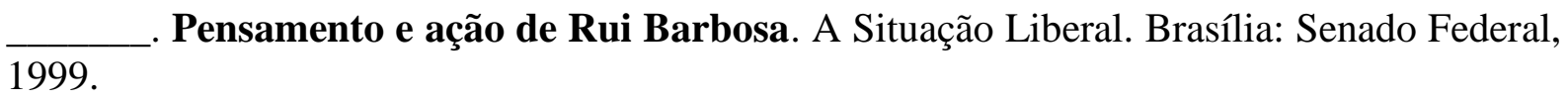

O estado de sítio: sua natureza, seus limites, seus efeitos. Capital Federal: Companhia Impressora, 1892.

BRASIL. Constituição da República dos Estados Unidos do Brasil de 1891. Disponível em: <http://www.planalto.gov.br/ccivil_03/constituicao/constituicao91.htm>. Acesso em: 18 de junho de 2016.

BRASIL. Constituição Política do Império do Brazil de 1824. Disponível em: <http://www.planalto.gov.br/ccivil_03/Constituicao/Constituicao24.htm>. Acesso em: $18 \mathrm{de}$ junho de 2016

CINTRA, Wendel Antunes. Liberalismo, justiça e democracia: a crítica de Rui Barbosa à experiência republicana brasileira. In: III Semana de Ciência Política da UFSCar. 'Democracia, conflito e desenvolvimento na América Latina'. São Carlos: Anais III Semana de Ciência Política, 2015.

LYNCH, Christian Edward Cyril. Cultura política brasileira. In: Gustavo Santos e Éder Brito, Política no Brasil. São Paulo,Oficina Municipal, 2015.

Da monarquia à oligarquia: História institucional e pensamento político brasileiro (1922-1930). São Paulo: Editora Alameda, 2014.

Monarquia sem despotismo e liberdade sem anarquia: o pensamento político do Marquês de Caravelas. Belo Horizonte: Editora UFMG, 2014. 
Por que pensamento e não teoria? A imaginação político-social brasileira e o fantasma da condição periférica (1880-1970). In: Revista de Ciências Sociais - DADOS. vol.56, n.4, p. 727-767. Rio de Janeiro, 2013.

RAMOS, Alberto Guerreiro. Administração e contexto brasileiro: Esboço de uma teoria geral da administração. $2^{\mathrm{a}}$ Ed. Rio de Janeiro: Editora da FGV, 1983.

\title{
BETWEEN BARBOSA'S UTOPIA AND THE REALITY OF CARAVELAS: \\ POLITICAL AND CONSTITUTIONAL THOUGHT OF THE MONARCHY 1824 \\ AND 1891 REPUBLIC
}

\begin{abstract}
The political-constitutional thinking that involves the formation of the Brazilian Monarchy 1824 and 1891 Republic is mainly a product from the reception of the theories circulating in the central countries in their time. How these ideas are received and applied differs in the ideological proposition of each of the historical characters. Federalist, republican, radical liberal and idealistic, Rui Barbosa is the main character in the drafting of the Constitution of 1891. Monarchist, liberal eighteenth century, enlightened and realistic, Marquis of Caravels is the main character in the drafting of the Constitution of 1824. The monarchy lasted 65 years and was aimed at the formation of the Brazilian state. The 1891 Republic lasted 39 years and was aimed at the democratization of the country and the liberation of the people. The Republic was a failure from the beginning, and the monarchy was able to create a State. The difference in methodological approach, the national intellectual subjection and the thought of these characters is what is proposed to investigate, for that it uses a specific literature review, as well as the revision of the texts written by the chosen characters.
\end{abstract}

Keywords: Brazilian political thought; utopian idealism; organic idealism; Brazilian constitutionalism. 